\title{
Ethnoveterinary Medicinal Plants Used by Ethnic and Rural People of Indo- Nepal Sub Himalayan International Border Region of Pilibhit Tiger Reserve (PTR), Uttar Pradesh, India.
}

\author{
${ }^{1}$ Gopal Dixit and ${ }^{1}$ Shilpa Vakshasya \\ Centre of Research in Ethnobotany, Department of Botany \\ Upadhi PG College, Pilibhit-262001, India. \\ Corresponding Author: gopaldixit2k@yahoo.com
}

\section{Manuscript Details}

Manuscript Submitted : 25/04/2019

Manuscript Revised : :03/05/2019

Manuscript Accepted : :10/05/2019

Manuscript Published : 15/05/2019

\section{$\underline{\text { Available On }}$}

https://plantaescientia.website/ojs

\section{Cite This Article As}

Dixit Gopal \& Shilpa Vakshasya (2019). Ethnoveterinary Medicinal Plants Used By Ethnic and Rural People of Indo- Nepal Sub Himalayan International Border Region of Pilibhit Tiger Reserve (PTR), Uttar Pradesh, India., Pla. Sci. 2019; Vol. 02 Iss. 01: 15-18.

DOI: https://doi.org/10.32439/ps.v2il.15-18

\section{Copyright}

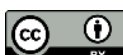

(c) The Author (s). 2019. Open Access This article is distributed under the terms of the Creative Commons Attribution 4.0 International License http://creativecommons.org/licenses/by/4.0/

Indexed In

Crossref, Index Copernicus International (ICI), Directory of Research Journal Indexing (DRJI), Scientific Indexing Services (SIS), CiteFactor,

\begin{abstract}
Tribal people are inhabiting indifferent locations of Pilibhit Tiger reserve region of Rohilkhand division of Uttar Pradesh state of India. Study area comprises of second largest forest cover among all the districts of Uttar Pradesh. This manuscript provides information on 21 medicinal plants belonging to 17 angiosperm families which are used by different tribal groups and indigenous people for curing various animal diseases. Few of the important medicinal plants are Achyranthus, Datura, Polygonum, Litsea, Bombax, Azadirachta etc. The use of locally growing, wild medicinal plants for curing different animal ailments was observed to be widespread and prevalent in this area.
\end{abstract}

Keywords: Ethnoveterinary plants, Indo- Nepal International border region, Pilibhit Tiger Reserve 
16 | Ethnoveterinary Medicinal Plants Used By Ethnic and Rural People of Indo-Nepal Sub Himalayan International Border Region of Pilibhit

Tiger Reserve (PTR), Uttar Pradesh, India.

\section{INTRODUCTION}

The use of indigenous plants to cure various animal diseases is known as ethnoveterinary. Study area falls under the IndoNepal sub-Himalayan region of UP state of India having international border with Nepal on North West periphery while Uttarakhand state on Northern side. District is located between $28^{\circ} 54^{\prime}-28^{\circ} 60^{\prime} \mathrm{N}$ latitude and $79^{\circ} 37^{\prime}-88^{\circ} 27^{\prime} \mathrm{E}$ longitude at an elevation of 183.870 meter above mean sea level. The sub-Himalayan Terai region of the study area is inhabited by the people of different tribes and indigenous people. They have to depend upon medicinal plants of their surroundings for the treatment of various ailments of domestic and pet animals. The chief objective of this study is identification, documentation and enumeration of ethno veterinary plants used for curing several animal diseases. The predominant tribes of the study area are Tharu, Van Gujjar and Kanjar. Among them Tharu is the major ethnic community. These people are mostly dependent on their generation-long traditional knowledge system for the treatment of their domestic animals and this knowledge has been passing from generation to generation through the words of mouth.

Various workers have contributed their ethno veterinary research findings on different ethnic groups from varied locations of India (Borthakur and Sarma,1996; Bhatt et.al, 2001; Mistry et al, 2003; Paul and Paul, 2006; Galav et al, 2007; Malik et al,2009; Vakshasya, 2009; Salam, 2013).

\section{METHODOLOGY}

Several visits of the study area were conducted, during last three years (2015-2018), in tribal inhabiting places in the vicinity of forests of PTR region. First-hand Information about the usage of plants in the treatment of animal ailments was collected through personal meetings with tribal heads (mukhiyas) and other experienced rural people of the study area. The information gathered was cross-checked with herbal practitioners (Bharras) and other experienced persons of the community. Plant specimens were collected from the sites and numbered properly for their identification with the help of available taxonomic literature, herbaria and floras etc. (Jain, 1981,2000). The numbered and taxonomically identified plant specimens have been deposited in the departmental herbarium of Upadhi PG College, Pilibhit. Vegetation of the study area comes under the Flora given by Duthie, 1973.Besides, Dixit and Vakshasya (2017) studied the common ethnoveterinary medicinal plants of the subHimalayan Terai region of the Rohilkhand division. In the present manuscript an attempt has been made to enlist ethnoveterinary herbal medicines of Indo Nepal subHimalayan Terai International border region of Pilibhit Tiger
Reserve of UP state of India. The usage and mode of preparation of ethnoveterinary drugs to cure different ailments of animals have been tabulated alphabetically in Table 1.

\section{RESULTS AND DISCUSSION}

The results of this study are chiefly based on local interviews with tribal and experienced rural people along with herbal practitioners. During the present ethnoveterinary survey, some very interesting herbal formulations have come into light which are even not mentioned in important published literature.

Some of ethnoveterinary plants which are occurring in the study area have showed remarkable medicinal properties which are very frequently used by ethnic and rural people. Plants often used by them are Calotropis procera, Adhatoda vasica, Curcuma amada, Achyranthus aspera, Azadirachta indica, Litsea glutinosa, etc. These plants would not only be cheap but also biodegradable and therefore eliminate the chance of any possible side effects caused by synthetic drugs. Among the documented indigenous practices of this study foot and mouth disease, indigestion, diarrhoea, fever, conjunctivitis, flatulence, skin diseases and bone fracture are primarily treated with locally growing wild medicinal plants. In the findings of present study different plant parts viz. roots, stem, leaves, tubers, juice etc. are very commonly used in various ethno veterinary treatments (Fig.l). These formulations need further laboratory tests to prove their efficacies and also to develop new veterinary herbal drugs for the sure cure of many animal diseases.

Fig.l. Graphical representation of number of plant parts used in different ethnoveterinary practices.

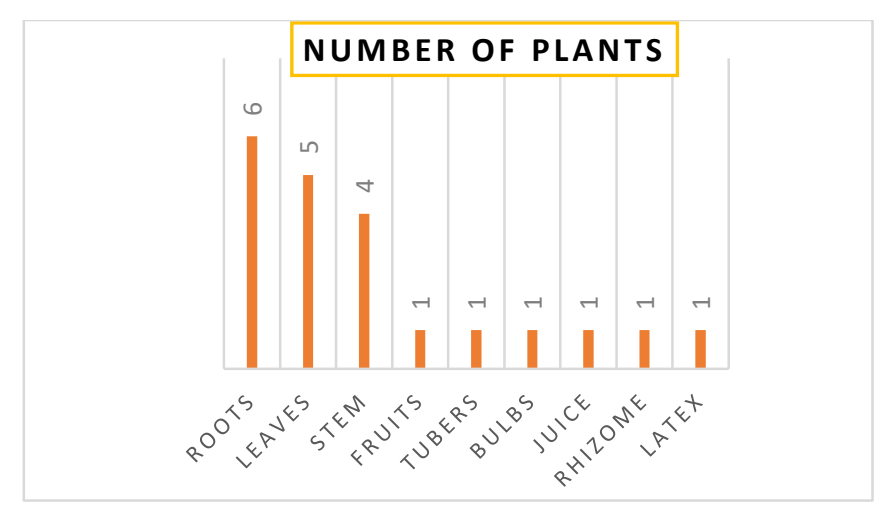

\section{ACKNOWLEDGEMENT}

The authors are grateful to Late Dr S.C. Sharma, Rtd. Head of Botany Department, G.F. College, Shahjahanpur for the proper identification of different wild plants. We are also thankful to Dr S.K. Rathore, Veterinary Officer, PTR for the 
identification of animal diseases. Library and literature support provided by librarian of Upadhi PG College, Pilibhit is highly solicited. We are also thankful to tribal heads and other experienced rural people along with herbalists for providing necessary first-hand information.

\section{REFERENCES}

Bhatt,DC; Mitalia, KD and Mehta, SK (2001). Observation on ethnoveterinary herbal practices in Gujrat. Ethnobot. 13 (91):

Borthakur,SK and Sarma, UK (1996). Ethno- Veterinary medicine with special reference to cattle prevalent among the Nepali's of Assam, India In: Ethnobiology in Human Welfareedited by Jain, SK, Deep Publication, New Delhi.

Dixit, Gopal and Vakshasya, Shilpa (2017). Ethnoveterinary plants used by different ethnic groups of Indo- Nepal sub-Himalayan terai region of Rohilkhand division of Uttar Pradesh state of India. Intl.J. Ad.Res.Med.Pharma.Sci.2 (8): 1-4.

Duthie, JF (1973) Flora of Upper Gangetic Plain and of the adjacent Shivalik and sub-Himalayan tracts. Botanical Survey of India, Calcutta, India. https://doi.org/10.5962/bhl.title.21629

Galav, PK; Nag, Ambika and Katewa, SS (2007). Traditional herbal veterinary medicines from Mount Abu, Rajasthan.Ethnobot 19: 120-123

Jain, SK (1981). Glimpses of Indian Ethnobotany. Oxford and IBH Publishing Co, New Delhi.

Jain, SK (2000).Plants in Indian Ethnoveterinary Medicine: Status and Prospects. Indian J Vet Med.21: 1-11.

Malik, Vijay; Mohammad, Inam and Bharagava, AK (2009). Enumeration of Ethnoveterinary plants of Saharanpur and Adjacent Shivalik hills. J. Ind. Bot.Soc. 88(3\&4): 77-81

Mistry, N; Silori,SC; Gupta,L and Dixit, AM (2003). Indigenous knowledge on animal healthcare practices in district Kuchchh, Gujarat. Indian J Trad Knowl.2(3):240.

Paul, CR and Paul, DC (2006). Traditional knowledge system about veterinary healthcare in and around of Bankura district, West Bengal, India, In: Herbal Medicine Traditional Practices, edited by Trivedi, PC; Aavishkar Publishers and Distributors, Jaipur.

Salam, S; Jamir, NS and Singh, PK (2013). Ethno-Veterinary plants of Ukhrul district, Manipur. Ethnobot.25 (1\&2): 139-142.

Vakshasya, Shilpa (2009).Ethnobotanical studies on the tribals of Pilibhit district, UP with special reference to their socio-economic upliftment. PhD Thesis, MJP Rohilkhand University, Bareilly, UP. 
18 | Ethnoveterinary Medicinal Plants Used By Ethnic and Rural People of Indo-Nepal Sub Himalayan International Border Region of Pilibhit Tiger Reserve (PTR), Uttar Pradesh, India.

Table 1: Showing Mode of Administration of different parts of the plants

\begin{tabular}{|c|c|c|c|c|c|}
\hline $\begin{array}{l}\text { Sr. } \\
\text { No }\end{array}$ & Family. & Botanical Name & $\begin{array}{l}\text { Local } \\
\text { Name }\end{array}$ & $\begin{array}{l}\text { Part } \\
\text { Used }\end{array}$ & Mode of Administration \\
\hline 1. & Acanthaceae & $\begin{array}{l}\text { Adhatoda zeylanica } \\
\text { Medic. }\end{array}$ & Vasaka & $\begin{array}{l}\text { Roots } \\
\text { Flowers }\end{array}$ & $\begin{array}{l}\text { Root bark decoction and black pepper } \\
\text { paste }(5: 2) \text { is given for safe discharge } \\
\text { of foetus. Fumes of burning flowers is } \\
\text { used to treat cough and cold }\end{array}$ \\
\hline 2. & Amaranthaceae & Achyranthes aspera L & Chirchita & Roots & $\begin{array}{l}\text { Roots are tied on the horns of } \\
\text { buffaloes for easy and safe delivery as } \\
\text { Touch Therapy. Fresh roots are placed } \\
\text { in vagina of the buffaloes for } \\
\text { expulsion of the placenta }\end{array}$ \\
\hline 3. & Anacardiaceae & Buchnania lanzen Spreng & Kath Bilwa & Leaves & $\begin{array}{l}\text { Fresh leaves decoction used to treat } \\
\text { bloody dysentery and diarrhoea }\end{array}$ \\
\hline 4. & Apocynaceae & Alstonia scholaris Linn. & Chatwaan & Latex & $\begin{array}{l}\text { Decoction of latex with black pepper } \\
\text { is given for expulsion of intestinal } \\
\text { worms }\end{array}$ \\
\hline 5. & Apocynaceae & $\begin{array}{l}\text { Carissa opaca Stapf ex. } \\
\text { Hains }\end{array}$ & $\begin{array}{l}\text { Jangli } \\
\text { Karonda }\end{array}$ & Roots & $\begin{array}{l}\text { Root powder is placed on worm } \\
\text { infested parts. }\end{array}$ \\
\hline 6. & Bignoniaceae & $\begin{array}{l}\text { Oroxylum indicum } \\
\text { (L)Vent }\end{array}$ & Sauna & Stem & $\begin{array}{l}\text { Stem bark paste is applied over } \\
\text { fractured bones. }\end{array}$ \\
\hline 7. & Bombacaceae & Bombax ceiba L & Simra & Stem & $\begin{array}{l}\text { Stem bark decoction cures diarrhea } \\
\text { and dysentery }\end{array}$ \\
\hline 8. & Caesalpiniaceae & Caesalpinia crista Linn & Khaja & Root & $\begin{array}{l}\text { Root decoction with black pepper } \\
\text { paste is given for expulsion of } \\
\text { placenta }\end{array}$ \\
\hline 9. & Caesalpiniaceae & Cassia fistula Linn & Sinara & Fruit & $\begin{array}{l}\text { Fruit powder, mustard oil and } \\
\text { turmeric powder }(4: 1: 2) \text { is given to } \\
\text { cure intestinal worms. }\end{array}$ \\
\hline 10. & Dioscoreaceae & Dioscorea bulbifera Linn & Belarkanda & Tubers & $\begin{array}{l}\text { Paste of tubers with long pepper } \\
\text { decoction is given in foot and mouth } \\
\text { disease. }\end{array}$ \\
\hline 11. & Euphorbiaceae & Ricinus communis Ben. & Andaua & Leaves & $\begin{array}{l}\text { Poultice of green leaves is applied over } \\
\text { ulcers. Oil is commonly used in } \\
\text { constipation. }\end{array}$ \\
\hline 12. & Lauraceae & $\begin{array}{l}\text { Litsea glutinosa (Lour) } \\
\text { CB Robbins }\end{array}$ & Maida & $\begin{array}{l}\text { Stem } \\
\text { Bark }\end{array}$ & $\begin{array}{l}\text { Fresh stem bark is applied externally } \\
\text { over the fractured bones. }\end{array}$ \\
\hline 13. & Leeaceae & $\begin{array}{l}\text { Leea asiatica }(\mathrm{L}) \\
\text { Ridstate }\end{array}$ & Golarkandra & Roots & $\begin{array}{l}\text { Root paste is applied over the septic } \\
\text { wounds }\end{array}$ \\
\hline 14. & Leeaceae & Leea macrophylla Roxb & Lathigaja & Leaves & $\begin{array}{l}\text { Paste of fresh leaves bandaged } \\
\text { externally over the fractured bones }\end{array}$ \\
\hline 15. & Liliaceae & Allium cepa L & Pyaz & Bulbs & $\begin{array}{l}\text { Extract of bulb and herbs are often } \\
\text { used in flatulence and dysentery }\end{array}$ \\
\hline 16. & Liliaceae & $\begin{array}{l}\text { Asparagus racemosus } \\
\text { Willd }\end{array}$ & Satawar & Roots & $\begin{array}{l}\text { Roots are given as vulnerary for } \\
\text { diarrhea and dysentery }\end{array}$ \\
\hline 17. & Malvaceae & $\begin{array}{l}\text { Abutilon indicum (L) } \\
\text { Sweet }\end{array}$ & Kanghi & Leaves & $\begin{array}{l}\text { Fresh leaves paste is applied over lice } \\
\text { affected parts of the body. }\end{array}$ \\
\hline 18. & Meliaceae & $\begin{array}{l}\text { Azadirachta indica A. } \\
\text { Juss. }\end{array}$ & Neeba & $\begin{array}{l}\text { Leaves, } \\
\text { Bark }\end{array}$ & $\begin{array}{l}\text { Decoction of leaves and bark is given } \\
\text { to baby animals for the expulsion of } \\
\text { intestinal worms. Paste of leaves is } \\
\text { applied to wounds to keep away flies. }\end{array}$ \\
\hline 19. & Mimosaceae & $\begin{array}{l}\text { Albizzia lebbeck (L) } \\
\text { Benth. }\end{array}$ & Sain & Stem & $\begin{array}{l}\text { Stem bark decoction is applied } \\
\text { externally on cattle sores. }\end{array}$ \\
\hline 20. & Papaveraceae & Argemone mexicana L & Kateri & Juice & $\begin{array}{l}\text { Green plant juice with onion bulb } \\
\text { juice is applied externally for killing } \\
\text { parasitic insects. }\end{array}$ \\
\hline 21. & Zingiberaceae & Curcuma amada Linn & Amahaldi & Rhizome & $\begin{array}{l}\text { Dried rhizome paste is applied over } \\
\text { fractured bones. }\end{array}$ \\
\hline
\end{tabular}

